Egypt. J. of Appl. Sci., 36 (5-6) 2021

\title{
INDUCING GENETIC VARIATION IN TARO USING GAMMA IRRADIATION
}

\author{
Amani H.A.M. Gharib
}

Vegetables, Medicinal and Aromatic Plant Breeding Department, Horticulture Research Institute, Agriculture Research Center, Giza, Egypt

Email - amani2468@gmail.com

Key Words: Taro, Colocasia esculenta L., gamma irradiation, Mutation, Yield, Quality.

\section{ABSTRACT}

This study was carried out during two successive seasons 2018 and 2019 at El-Kanater El-Khyreia, Horticulture Research Station of Hort. Res. Institute (Kaluobia Governorate), Agriculture Research Center (ARC), Egypt, the present investigation was carried out to study the effect of four gamma rays doses, 30, 60, 90 and $120 \mathrm{~Gy}$ in addition to Gy 0 (control), on yield and its components of Taro during two generations (M1and M2) in the two growing seasons 2018 and 2019. 120 Gy had lethal effect where it resulted in no germination.

The results showed highly significant mean squares for all the studied traits in both two generations indicating considerable variations between the four treatments, while, phenotypic coefficient of variation was higher than that of genotypic coefficient of variation for all traits. Gamma ray affected widely the genetic variation making it good way to select new lines in taro. The 30 Gy dose was the best producing maximum variation in M2 generation. Selection was done on the plants under that dose to select the better plants were selected according to high vegetative growth, plant height, number of leaves per plant, number of corms, corm length, corm weight and diameter as well as corm shape index. Results of evaluated M2 generation clones can be summarize as follows: selection based on weight of corm was efficient to increase total yield and corm quality, the clone's number 3, 4 and 5 produced the highest number of corms / plant and the highest corm weight. the selected clone's number 3, 4 and 5 are recommended for cultivation in Delta Governorates Egypt.

\section{INTRODUCTION}

Mutations are one of the main sources through inducing variations in plants where irradiation produces the most mutants (Beyaz and Yildiz 2017 and Fadli et al., 2018). Gamma rays are short electromagnetic waves that can create physical mutagens free radicals in cells and induce mutations in plants as free radicals make cellular damage influential effect on plant cell components (Fadli $\boldsymbol{e t}$ al., 2018). Inducing mutations by Gamma ray is an important artificially way to improve crops in plant breeding programs. Physical mutagens (Gamma rays improved 1604 mutants) were used more regularly as comparing to 
chemical mutagens and novel plant germplasm (Parry et al.,2009; Penna et al., 2012 and Beyaz and Yildiz, 2017).

According to international health and safety authorities; Joint FAO/IAEA/WHO/FDA Expert Committee on the Wholesomeness of Irradiated Foods (JECFI), foods irradiated up to $10 \mathrm{kGy}$ are considered safe and present no toxicological hazard and no special nutritional or microbiological problems in food (Anonymous, 1981). Gamma radiation of 30-1000 Gy has been applied to achieve a delay in the ripening of some fruits and vegetables (WHO 1988). Gamma rays can be also used for inhibiting sprouting and decay in some stored vegetables such as potato, garlic and onion up to $120 \mathrm{~Gy}$ without health hazards as found (Adejumo 1998 and Bansa and Appiah 2003).

Gamma rays were used to inducs mutations in seeds and other plant materials such as cuttings, pollens and tissue-cultured calli (Ali $\boldsymbol{e t}$ al., 2016 and Oladosu et al., 2016). The Gamma rays effect on taro morphophysio-biochemical properties against Phytophthora leaf blight is documented (Sahoo et al., 2012).

Taro (Colocasia esculenta L.) tubers are one of main food crops for millions of people in the developing world for its edible underground stem (corm) and its good adaptability, resistance to different diseases and ability to produce high amount of yields in different areas especially on tropical environments (Tewodros, 2012 and Mulualem et al.,2013).Taro contains healthy and safe food components, as it has low carbohydrate content $(27.25 \%)$, sugars $(0.87 \%)$ and starch content $(24.11 \%)$, also has lower glycemic index (GI) comparing to other carbohydrate sources and contain bioactive ingredients that are efficacious for health (Rudyatmi and Enni, 2014 and Sundari et al., 2014).

The major benefit of mutation induction in vegetative propagated plants is the ability to create one or few characters without changing the remaining unique characters.

Food does not become radioactive as the energy passes through; it only destroys bacteria and does not leave behind any residual radioactivity (Fox, 2002; Hayes et al., 2002). It is indicated that given the preference and the Gamma Irradiation for Fresh Produce 257 access to irradiated products, consumers are willing to purchase them in noticeably great number (Bruhn, 1998). Many expert authorities have reviewed the evidence over the years, and concluded that irradiated foods do not pose significant health risks to people who eat them. 
GCV and PCV values were categorized as low (0-10\%), moderate (10-20\%) and high (20\% and above) following Sivasubramanian and MadhavaMenon (1973) classification. The heritability percentage was categorized as low (0-30\%), moderate $(30-60 \%)$ and high $(\geq 60 \%)$ in accordance to Robinson $\boldsymbol{e t}$ al. (1949). Genetic advance as percentage of mean was categorized as low (0-10\%), moderate (10-20\%) and high (>20\%) as outlined by Johnson et al. (1955).

The objective of the present study was to evaluate the effects of five does of gamma-rays on yield and corm traits of Taro during two generations M1 and M2. Also, the study extended to select the most desirable plants in M2 population.

\section{MATERIALS AND METHODS}

The experiment was carried out at El-Kanater El-Khyreia, Horticulture Research Station of Hort. Res. Institute (Kaluobia Governorate), Agriculture Research Center (ARC), Egypt, during two successive growing seasons 2018 and 2019 on Taro (Colocasia esculenta L.) Balady local variety. Corms were irradiated with 0, 30, 60, 90 and 120 Gy using Cobalt-60 gamma rays. The time of exposure was 20 mints. The irradiation source was the cyclotron project, Nuclear Research Center, Atomic Energy Authority, Cairo, Egypt. The dose rate of the source was $7.0 \mathrm{~Gy} / \mathrm{min}$.

In $18^{\text {th }}$ February 2018, 1000 Balady local variety cormles were irradiated and grown to raise plants of M1 generation planted in randomized complete blocks design with three replicates. All the M1 corms were harvested at 270 days separately for raising M2 generation.

In $5^{\text {th }}$ February 2019 growing season, the M1 corms from the irradiation doses were sown to produce M2 plants. Corms selected were planted in randomized complete blocks design with three replicates during the two growing seasons. The experimental was contained 3 rows, with $3 \mathrm{~m}$ length, $30 \mathrm{~cm}$ between them and $0.80 \mathrm{~m}$ width. All normal agricultural practices for cultivation were applied as recommended by Ministry of Agriculture during the two growing seasons.

Recorded data: Data were recorded on 10 individual plants in both generations M1 and M2 to estimate; Plant height (cm), number of leaves per plant, number of corms, corm length $(\mathrm{cm})$, corm weight $(\mathrm{kg})$, corm diameter and corm shape index $(\mathrm{cm})$.

\section{Statistical procedures:}

Data were recorded on individual plants on random samples of ten guarded plants from each M1 and M2. The means of the ten plants were 
subjected to the statistical analysis according to Snedecor and Cochran (1980).

Genotype means, ranges, coefficients of variation (CV \%) and standard errors of the M1 and M2 populations were calculated for all the studied traits from raw data. Also, a separate analysis of variance (ANOVA) was performed for all the studied traits in M1 and M2 generations according to Snedecor and Cochran (1980). Whereas, means were compared by using the least significant difference (LSD) test at $5 \%$ probability levels.

Genotypic and phenotypic coefficient of variance, heritability in broad sense, genetic advance (GA) and genetic advance as a percentage of mean (GAM) were calculated using the formula given by Falconer (1981). Desirable plants were selected in $\mathrm{M} 2$ generation at 5\% level of selection intensity. Skewness and kurtosis were calculated as well as normality of distribution was tested by Shapiro-Wilk W test for all studied traits (De Carlo, 1997).

\section{RESULTS AND DISCUSSION}

The irradiated doses showed high survival rate (above $80 \%$ ), except the dose $120 \mathrm{~Gy}$ which is considered as the lethal dose of $50 \%$ deaths (LD50). So, the study estimates the effect of Gamma doses 0 (control), 30, 60 and 90 Gy on Balady Taro variety during M1 and M2 generations on seven economic traits.

Mean performance of $\mathrm{M} 1$ and M2 generations plants: Significant differences were observed among the treatments of gamma rays and the control for most of the studied traits (Table 1).

Plant height results illustrated (Table 1), were high in all applied doses. There was a gradual decrease for plant height by gamma rays dose decreasing and significant differences at 0.05 were found between control and all treatments. Based on observations of plant height, high doses (gray) greatly affected the height of taro plant, the higher dose was given the lower height of taro plant. Similar results were obtained by Fadli et al. (2018). High decrease in plants or plants becomes stunted due to the influence of high doses due to physiological disorders or chromosomal damage caused by mutagen (gamma ray radiation). Gamma rays belong to pegionic radiation and interact with atoms or molecules to produce free radicals (losing one electron from the free electron pair) in the cell. These radicals can damage or modify very important components in plant cells and cause partial changes of morphology, anatomy, biochemistry and plant physiology depending on 
the level of radiation. This showed mutation breeding can create genetic diversity in quantitative characters, so that it affects plants growth (AlSafadi et al., 2009).

Number of leaves: The used treatments showed differences in number of leaves between 30,60, 90 and control. Number of leaves were affected significantly by increasing gamma rays treatments and the highest number of leaves was obtained from 30 Gy treatments (Puchooa, 2005 and Nurilmala et al., 2017).

Number of corms and corm traits: Number of corms were affected significantly by increasing gamma rays doses where the treatment $30 \mathrm{~Gy}$ Gamma rays produced the highest number of corms, which was significantly higher than the corm number of untreated plants (control) as well as the rest of doses. Moustafa et al. (2018) reported that $30 \mathrm{~Gy}$ Gamma rays produced the highest value in number of corms, maximum number of corms per plant in M1 and M2 generation. Kumari and Kumar (2015) found minimum number of corms per plant was resulted at the highest dose of gamma rays (90Gy).

Table 1: Phenotypic mean performance for the studied traits over three doses of gamma rays compared with control through M1 and M2 generations of Taro.

\begin{tabular}{|c|c|c|c|c|c|c|c|c|}
\hline \multirow{2}{*}{$\begin{array}{c}\text { Traits } \\
\text { Treatments }\end{array}$} & \multicolumn{2}{|c|}{$\begin{array}{l}\text { Plant height } \\
\text { cm }\end{array}$} & \multicolumn{2}{|c|}{ No. of leaves } & \multicolumn{2}{|c|}{ No. of corm } & \multicolumn{2}{|c|}{$\begin{array}{c}\text { Corm Weight } \\
\text { kg }\end{array}$} \\
\hline & M1 & M2 & M1 & M2 & M1 & M2 & M1 & M2 \\
\hline 30 Gamma & 225.810 & 231.200 & 4.000 & 4.500 & 3.900 & 3.900 & 1.666 & 1.847 \\
\hline 60 Gamma & 186.750 & 188.660 & 3.300 & 3.200 & 3.100 & 3.000 & 0.517 & 0.572 \\
\hline 90 Gamma & 167.630 & 173.210 & 2.300 & 3.500 & 2.700 & 2.600 & 0.456 & 0.407 \\
\hline Control & 221.630 & 222.600 & 3.600 & 3.700 & 3.100 & 2.900 & 0.783 & 0.763 \\
\hline Grand mean & 200.455 & 203.918 & 3.300 & 3.725 & 3.200 & 3.100 & 0.856 & 0.897 \\
\hline LSD at 0.05 & 5.064 & 9.291 & 0.487 & 0.534 & 0.336 & 0.543 & 0.068 & 0.138 \\
\hline LSD at 0.01 & 8.191 & 15.030 & 0.787 & 0.864 & 0.543 & 0.543 & 0.110 & 0.222 \\
\hline \multirow{2}{*}{$\begin{array}{c}\text { Traits } \\
\text { Treatments }\end{array}$} & \multicolumn{2}{|c|}{$\begin{array}{c}\text { Corm Length } \\
\text { cm }\end{array}$} & \multicolumn{2}{|c|}{$\begin{array}{c}\text { Corm Diameter } \\
\text { cm }\end{array}$} & \multicolumn{2}{|c|}{ Corm Shape } & & \\
\hline & M1 & M2 & M1 & M2 & M1 & M2 & & \\
\hline 30 Gamma & 11.360 & 11.770 & 9.770 & 10.580 & 1.333 & 1.387 & & \\
\hline 60 Gamma & 9.050 & 10.130 & 8.810 & 8.490 & 1.079 & 1.245 & & \\
\hline 90 Gamma & 8.090 & 9.620 & 7.920 & 7.480 & 0.955 & 0.916 & & \\
\hline Control & 10.150 & 10.280 & 9.690 & 9.534 & 1.184 & 1.062 & & \\
\hline Grand mean & 9.663 & 10.450 & 9.048 & 9.021 & 1.138 & 1.152 & & \\
\hline LSD at 0.05 & 1.019 & 0.935 & 0.560 & 1.031 & 0.089 & 0.143 & & \\
\hline LSD at 0.01 & 1.648 & 1.513 & 0.905 & 1.668 & 0.143 & 0.231 & & \\
\hline
\end{tabular}

Analysis of variance: In order to demonstrate the differences between the studied traits analysis of variance (ANOVA) was performed during 
two generations M1 and M2 as presented in Table (2). The results showed that all the studied traits showed highly significant differences $(p<0.01)$ in both generations. These results reflected the effect of Gamma rays on Taro. The coefficient of variance (CV \%) ranged from 4.780 for plant height to 21.505 for number of corms. The traits with CV\% between $10 \%$ and $20 \%$ are having "moderate variability", while traits with CV\% greater than $20 \%$ had "high variability" (Gomez and Gomez, 1984).

Table (2): Analysis of variance for the studied traits during M1 and M2 generations of Taro.

\begin{tabular}{|c|c|c|c|c|c|c|c|c|c|}
\hline \multicolumn{10}{|c|}{ Traits } \\
\hline & \multirow{2}{*}{ d.f } & \multicolumn{2}{|c|}{ Plant height } & \multicolumn{2}{|c|}{ Number of leaves } & \multicolumn{2}{|c|}{ Number of corms } & \multicolumn{2}{|c|}{ Corm weight } \\
\hline & & M1 & M2 & M1 & M2 & M1 & M2 & M1 & M2 \\
\hline Replications & 2 & 22.969 & 9.604 & 0.037 & 0.100 & 0.009 & 0.065 & 0.000 & 0.004 \\
\hline Treatments & 3 & $2355.708 * *$ & $2289.076 * * *$ & $1.483 * *$ & $0.850 *$ & $0.730 * *$ & $0.878 * *$ & $0.928 * *$ & $1.278 * *$ \\
\hline Error & 6 & 10.189 & 34.301 & 0.094 & 0.113 & 0.045 & 0.045 & 0.002 & 0.008 \\
\hline \multicolumn{2}{|l|}{$\begin{array}{c}\text { Coefficient of } \\
\text { variation \% }\end{array}$} & 4.780 & 6.710 & 15.442 & 13.251 & 17.359 & 25.162 & 7.745 & 17.951 \\
\hline & & \multicolumn{2}{|c|}{ Corm length } & \multicolumn{2}{|c|}{ Corm diameter } & \multicolumn{2}{|c|}{ Corm shape index } & & \\
\hline & & M1 & M2 & M1 & M2 & M1 & M2 & & \\
\hline Replications & 2 & 0.702 & 0.319 & 0.626 & 0.763 & 0.002 & 0.009 & & \\
\hline Treatments & 3 & $6.094 * *$ & 2.614* & $2.234 * *$ & $5.761 * *$ & $0.074 * *$ & $0.118 * *$ & & \\
\hline Error & 6 & 0.412 & 0.347 & 0.124 & 0.422 & 0.003 & 0.008 & & \\
\hline $\begin{array}{c}\text { Coefficient of } \\
\text { variation \% }\end{array}$ & & 10.450 & 7.371 & 9.058 & 8.545 & 12.192 & 10.871 & & \\
\hline
\end{tabular}

As shown in Table (3) phenotypic variation was higher in magnitude than the genotypic variation in respect to all traits. This suggesting the existence of genetic variability but the phenotypic variations were also moderately influenced by the environment as well as interactions at different levels. Maximum phenotypic coefficient of variance (PCV \%) was observed for plant height (280.792 M1, 275.003 M2) followed by corms weight (60.259 M1, 69.326 M2), corm length (48.855 M1, $32.486 \mathrm{M} 2$ ), number of corms (35.236 M1, 39.190 M2). Maximum genotypic coefficient of variation (GCV \%) was observed for plant height (278.980 M1, 268.935 M2) followed by corms weight (60.081 M1, 68.719 M2), corm length (44.275 M1, 26.886 M2), number of corms (32.220 M1, 36.370 M2). In the present study phenotypic coefficient of variation was higher than that of genotypic coefficient of variation for all traits. The same results were reported by Paul $\boldsymbol{e t}$ al. (2011) and Kumar et al. (2017). That indicated those traits interacted with the environments to a considerable extent. Also, moderate differences between PCV and GCV indicating some amount of variability were found between the studied materials, depicting the possibility for improvement through selection in later generations. 
Table (3): Phenotypic mean performance, standard error (SE), broad sense heritability $\left(\mathrm{h}^{2}{ }_{\mathrm{bs}}\right)$, genetic advance (GA) and genetic advance as percentage of mean (GAM) during M1 and M2 generations of Taro.

\begin{tabular}{|c|c|c|c|c|c|c|c|c|}
\hline \multicolumn{9}{|c|}{ Traits } \\
\hline \multirow[t]{2}{*}{ Variables } & \multicolumn{2}{|c|}{$\begin{array}{l}\text { Plant height } \\
(\mathrm{cm})\end{array}$} & \multicolumn{2}{|c|}{ Number of leaves } & \multicolumn{2}{|c|}{ Number of corms } & \multicolumn{2}{|c|}{$\begin{array}{c}\text { Corm weight } \\
\text { (g) }\end{array}$} \\
\hline & M1 & M2 & M1 & M2 & M1 & M2 & M1 & M2 \\
\hline Mean & 100.455 & 103.918 & 3.300 & 3.725 & 2.200 & 2.100 & 0.856 & $\mathbf{0 . 8 9 7}$ \\
\hline SE & 1.507 & 2.157 & 0.154 & 0.155 & 0.113 & 0.155 & 0.024 & 0.036 \\
\hline SD & 4.766 & 6.821 & 0.488 & 0.490 & 0.358 & 0.491 & 0.076 & 0.115 \\
\hline $\mathbf{V}_{\mathrm{ph}}$ & 781.840 & 751.592 & 0.463 & 0.245 & 0.228 & 0.278 & 0.309 & 0.424 \\
\hline$V_{g}$ & 792.029 & 785.892 & 0.557 & 0.359 & 0.273 & 0.323 & 0.311 & 0.431 \\
\hline PCV \% & 280.792 & 275.003 & 41.087 & 31.036 & 35.236 & 39.190 & 60.259 & 69.326 \\
\hline GCV \% & 278.980 & 268.935 & 37.456 & 25.665 & 32.220 & 36.370 & 60.081 & 68.719 \\
\hline $\mathbf{h}_{\text {bs }}^{2}$ & 0.987 & 0.956 & 0.831 & 0.684 & 0.836 & 0.861 & 0.994 & 0.983 \\
\hline GA & 4.766 & 6.821 & 0.488 & 0.490 & 0.358 & 0.491 & 0.076 & 0.115 \\
\hline \multirow[t]{3}{*}{ GAM \% } & 9.668 & 13.405 & 0.834 & 0.688 & 0.615 & 0.870 & 0.155 & 0.233 \\
\hline & \multicolumn{2}{|c|}{$\begin{array}{l}\text { Corm length } \\
\text { (cm) }\end{array}$} & \multicolumn{2}{|c|}{$\begin{array}{l}\text { Corm diameter } \\
\text { (cm) }\end{array}$} & \multicolumn{2}{|c|}{ Corm shape index } & & \\
\hline & M1 & M2 & M1 & M2 & M1 & M2 & & \\
\hline Mean & 9.663 & 10.450 & 9.048 & 9.021 & 1.138 & 1.152 & & \\
\hline SE & 0.320 & 0.245 & 0.247 & 0.231 & 0.044 & 0.041 & & \\
\hline SD & 1.013 & 0.775 & 0.781 & 0.731 & 0.139 & 0.130 & & \\
\hline $\mathbf{V}_{\mathrm{ph}}$ & 1.894 & 0.755 & 0.703 & 1.780 & 0.023 & 0.037 & & \\
\hline $\mathbf{V}_{g}$ & 2.306 & 1.103 & 0.828 & 2.202 & 0.027 & 0.045 & & \\
\hline PCV \% & 48.855 & 32.486 & 30.248 & 49.406 & 15.293 & 19.686 & & \\
\hline GCV \% & 44.275 & 26.886 & 27.881 & 44.417 & 14.368 & 17.810 & & \\
\hline $\mathbf{h}_{\text {bs }}^{2}$ & 0.821 & 0.685 & 0.850 & 0.808 & 0.883 & 0.818 & & \\
\hline GA & 1.013 & 0.775 & 0.781 & 0.731 & 0.139 & 0.130 & & \\
\hline GAM \% & 1.710 & 1.091 & 1.364 & 1.214 & 0.253 & 0.219 & & \\
\hline
\end{tabular}

Broad sense heritability $\left(\mathrm{h}_{\text {bs }}^{2}\right)$ was calculated as the ratio between total phenotypic variance to genetic variance as presented in Table (3). Most of the studied traits had higher heritability (more than $60 \%$ ). The higher heritability values indicated that selection can be done in early generations. Genetic advance ranged from 0.781 (corm diameter) to 0.076 (corm weight) in M1 generation and from 1.013 (corm length) to 0.115 (corm weight) in M2 generation.

Plant breeder can use both parameters of heritability and genetic advance, as a percent of mean (GAM), to indentify gene action for the studied traits. In the present study, both parameters were calculated in both generations as shown in Table (3). Two traits had higher values of heritability $(9.668,13.405$ for plant height, $0.155,0.233$ for corm weight in M1 and M2 generations, respectively, coupled with high genetic advance as a percent of mean. These results indicated that additive gene action controlling these two traits. Therefore, these traits can be improved through selection in early generations (Paul et al., 2011 and 
Kumar et al., 2017). While, the remaining traits had higher heritability values coupled with low genetic advance as percent of mean or low heritability values with low GAM indicating that these traits controlled by non-additive gene action (dominance or epistasis if present) as found by Kumar et al. (2017); Paul et al. (2011) and Cheema et al. (2007). The combination between these two parameters provides better information to the breeder to how selects using heritability or genetic advance alone and considerable improvement could be done by selecting the best individual. Also, similar results had been reported by Cheema $\boldsymbol{e t}$ al. (2007) and Choudhary et al. (2011).

In the current study, data show that $30 \mathrm{~Gy}$ dose was the best dose which produced the maximum variability in M2 generation, where the study focused on the plants were produced from this dose and selected the most promising plants to form the M3 generation. More details about that dose are given in Table (4) and Figure (1). The maximum phenotypic mean performance for all the studied traits was recorded under 30 Gy dose. Selection was done on the plants under this dose to select the best plants which had higher mean values more than the grand mean of M2 generation. Selection was done under $5 \%$ selection intensity pressures to select the best five plants from the M2 population under that dose only. As presented in Table (5) all selected plants had higher phenotypic mean performance than the original population. Those plants would form the M3 generation in the next season.

Table (4): Statistics for the 30 Gamma ray overall the studied traits

during M2 generation of Taro.

\begin{tabular}{|c|c|c|c|c|c|c|c|}
\hline \multicolumn{8}{|c|}{ Traits } \\
\hline \multirow[t]{2}{*}{ Statistics } & $\begin{array}{c}\text { Plant height } \\
(\mathrm{cm})\end{array}$ & $\begin{array}{c}\text { Number of } \\
\text { leaves }\end{array}$ & $\begin{array}{c}\text { Number of } \\
\text { corms }\end{array}$ & $\begin{array}{c}\text { Corm } \\
\text { weight } \\
\text { (g) }\end{array}$ & $\begin{array}{c}\text { Corm length } \\
(\mathrm{cm})\end{array}$ & \begin{tabular}{|c} 
Corm \\
diameter \\
$(\mathrm{cm})$
\end{tabular} & $\begin{array}{l}\text { Corm } \\
\text { shape } \\
\text { index }\end{array}$ \\
\hline & \multicolumn{7}{|c|}{ Original population } \\
\hline Mean & 131.200 & 4.500 & 2.800 & 1.847 & 11.770 & $\mathbf{1 0 . 0 3 0}$ & 1.387 \\
\hline Standard Error & 0.904 & 0.167 & $\mathbf{0 . 1 3 3}$ & 0.095 & 0.273 & 0.385 & 0.068 \\
\hline Median & 130.000 & 4.500 & 3.000 & 1.825 & 12.000 & 10.600 & 1.408 \\
\hline Standard Deviation & 2.860 & 0.527 & 0.422 & 0.300 & 0.863 & 1.218 & 0.216 \\
\hline Variance & 8.178 & 0.278 & 0.178 & 0.090 & 0.745 & 1.485 & 0.047 \\
\hline Skewness & 0.306 & -0.087 & -1.103 & 0.067 & 0.569 & 0.000 & -1.779 \\
\hline \multirow[t]{2}{*}{ Kurtosis } & -0.288 & 1.147 & -0.559 & -1.543 & -0.607 & -2.571 & 1.406 \\
\hline & \multicolumn{7}{|c|}{ Selected population } \\
\hline Mean & 133.000 & 4.600 & 2.800 & 1.895 & 11.840 & 10.740 & 1.488 \\
\hline Standard Error & 1.265 & 0.245 & 0.200 & 0.187 & 0.186 & 0.117 & 0.106 \\
\hline Median & $\mathbf{1 3 4 . 0 0 0}$ & 5.000 & 3.000 & 1.876 & 12.000 & 10.700 & 1.609 \\
\hline Standard Deviation & 2.828 & 0.548 & 0.447 & 0.418 & 0.416 & 0.261 & 0.238 \\
\hline Variance & 8.000 & 0.300 & 0.200 & 0.175 & 0.173 & 0.068 & 0.057 \\
\hline Selection differential & 0.048 & 0.070 & 0.160 & 0.101 & 1.800 & 0.100 & 0.100 \\
\hline GA & 0.233 & 1.092 & 1.215 & 0.219 & 13.412 & 0.689 & 0.870 \\
\hline GAM\% & 12.288 & 9.222 & 11.311 & 14.711 & 10.084 & 14.968 & 29.001 \\
\hline
\end{tabular}


Table (5): Mean performance for the selected M2 plants from 30 gamma ray over the studied traits of Taro.

\begin{tabular}{|c|c|c|c|c|c|c|c|}
\hline $\begin{array}{c}\text { Number of } \\
\text { selected } \\
\text { plants }\end{array}$ & $\begin{array}{c}\text { Plant } \\
\text { heigh } \\
\mathbf{t} \\
(\mathbf{c m})\end{array}$ & $\begin{array}{c}\text { Number } \\
\text { of } \\
\text { leaves }\end{array}$ & $\begin{array}{c}\text { Number } \\
\text { of } \\
\text { corms }\end{array}$ & $\begin{array}{c}\text { Corm weight } \\
(\mathrm{g})\end{array}$ & $\begin{array}{c}\text { Corm length } \\
(\mathbf{c m})\end{array}$ & $\begin{array}{c}\text { Corm } \\
\text { diameter } \\
(\mathrm{cm})\end{array}$ & $\begin{array}{c}\text { Corm shape } \\
\text { index }\end{array}$ \\
\hline 3 & 130.000 & 4.000 & 3.000 & 2.317 & 12.000 & 10.600 & 1.385 \\
\hline 4 & 135.000 & 5.000 & 3.000 & 2.304 & 12.000 & 11.000 & 1.636 \\
\hline 5 & 134.000 & 4.000 & 3.000 & 1.876 & 12.100 & 10.700 & 1.693 \\
\hline 6 & 136.000 & 5.000 & 2.000 & 1.598 & 12.000 & 10.400 & 1.118 \\
\hline 7 & 130.000 & 5.000 & 3.000 & 1.380 & 11.100 & 11.000 & 1.609 \\
\hline Mean & 133.000 & 4.600 & 2.800 & 1.895 & 11.840 & 10.740 & 1.488 \\
\hline
\end{tabular}

Skewness and kurtosis values describe the symmetry and vertex of the sampled distributions relative to the normal distribution are shown in Figure (1) for 30 Gy dose. The current study considered both skewness and kurtosis should be zero for a perfectly normally distributed variable (De Carlo, 1997). In fact, the ideal kurtosis value is three but most statistical packages subtract 3 from the value so that both skew and kurtosis ideal values are zero. Thus, the negative value of skewness indicates that skewness to the left and positive values indicated skewness to the right. Data presented in Table (4) revealed slightly negative to positive skewness. A positive skewness values were recorded for plant height, corm weight, corm length and corm diameter, while negative values were observed for number of leaves, number of corm and corm shape index. Positive skewness, though a value of zero does not necessarily indicate perfect symmetry. On the other hand, Kurtosis measures the apex of a distribution. A positive value typically indicates that the distribution has a sharper peak, thinner shoulders, and fatter tails than the normal distribution. The low values of both skewness and kurtosis over all studied traits under 30 Gy dose reflect solid confirmation of data homogeneity and normality.

It could be concluded that gamma rays affected widely the variability and breeder can select excellent strains through 30 Gy treatment, while, the treatment 120 Gy was lethal and stopped germination in Taro corms. The $30 \mathrm{~Gy}$ dose was the best producing maximum variation in M2 generation. Selection was done on the plants under this dose to select the better plants were selected according to high vegetative growth, plant height, number of leaves per plant, number of corms, corm length, corm weight, corm diameter and corm shape index. Results of evaluated M2 generation clones can be summarize as follows: selection based on weight of corm was efficient to increase total yield and corm quality, the clone's number 3,4 and 5 produced the highest number of corms / plant and the highest corm weight. the selected clone's number 3, 4 and 5 are recommended for cultivation in Delta Egypt. 


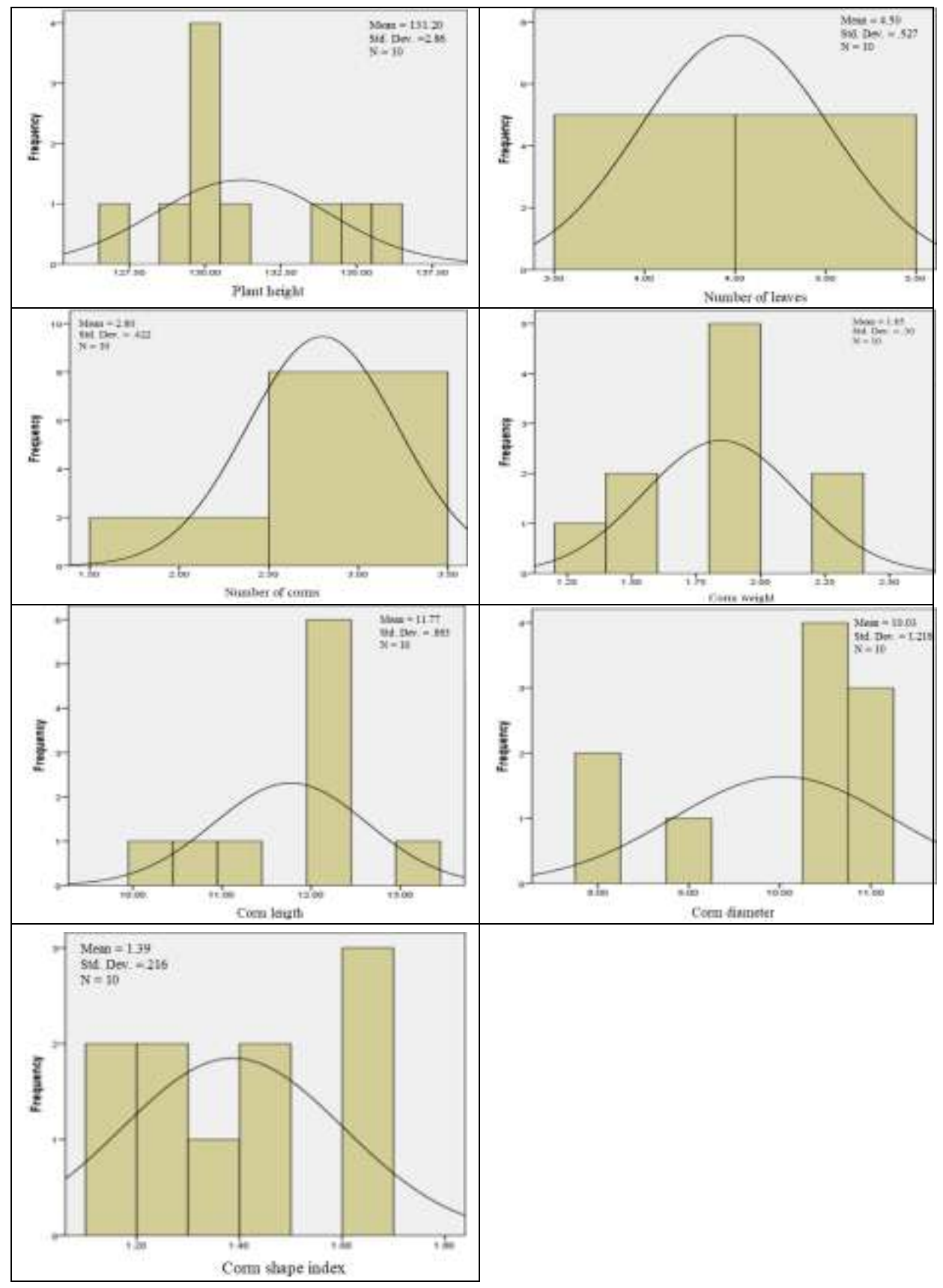

Figure (1). Normal distribution curve for M2 of the 30 Gamma dose overall the studied traits of Taro. 


\section{ACKNOWLEDGEMENT}

The author is grateful to Dr. Ahmed Mohamed Abdelmoghny $(\mathrm{PhD})$, Senior Researcher (Cotton Breeder) at Cotton Breeding Department, Cotton Research Institute (CRI), Agricultural Research Center (ARC). Also, Dr. Amr Mounir (PhD), Researcher at Nuclear Research Center, Atomic Energy Authority for encouragement, helping and cooperation.

\section{REFERENCES}

Adejumo, J. (1998). Food preservation by gamma irradiation BSc Project Department of Physics, Obafemi Awolowo University, Ile-Ife, Nigeria.

Ali, H. ; Z. Ghori ; S. Sheikh and A. Gul (2016). Effects of gamma radiation on crop production. In: Hakeem KR, editor. Crop Production and Global Environmental Issues. Springer International Publishing, Switzerland. pp. 27-78.

Al-Safadi, B. ; Z. Ayyoubi and and D. Jawdat (2000). The effect of gamma irradiation on potato micro tuber production in vitro. Plant Cell Tissue and Organ Culture, 61(3):183-187.

Anonymous, (1981). Wholesomeness of irradiated food report of a joint FAO/IAEA/ WHO expert committee. Technical Report Series: 659. WHO, Geneva.

Bansa, D. and V. Appiah (2003). Preservation of yams by gamma radiation J. Ghana Sci. Assoc., 1: 3.

Beyaz, R. and M. Yildiz (2017). The Use of Gamma Irradiation in Plant Mutation. Breeding in Book Plant Engineering. Pp. 33-46.

Bruhn, C. M. (1998). Consumer acceptance of irradiated food: Theory and reality. Radiation Physics and Chemistry, 52:129-133.

Cheema, D. S. ; H. Singh; A. S. Dhatt; A. S. Sidhu and N. Garg (2007). Studies on Genetic Variability and Correlation for Yield and Quality Traits in Arvi (Colocasia esculenta L.). Schott. Acta, Horticulture, 752:255-260.

Choudhary, V. K. ; S. P. Kumar ; J. George ; M. Kanwat and R. Saravanan (2011). Genetic variability and correlation for yield and quality traits in Taro under mid-hills of Arunachal Pradesh. J. Root Crops, 37(2): 155-161.

Fadli, N. ; Z. Syarif; B. Satria and N. Akhir (2018). The Effect of Gamma Cobalt-60 Ray Irradiation on Cultivar Growth in Taro White (Xhanthosoma Sagittifolium L.). Int. J. of Env., Agric. and Biotech. (IJEAB), 3 (6): 2020-2025. 
Falconer, D. S. (1981). Introduction to Quantitative Genetics. $2^{\text {nd }}$ Ed. Longman Inc., New York.

FDA (1986). Irradiation in the production, processing and handling of food. Food and Drug Administration (Federal Register), 51(75): $13376-13399$.

Fox, J.A. (2002). Influence on purchase of irradiated foods. Food Technol., 56(11): 34-37.

Gomez, K.A. and A.A. Gomez (1984). Statistical procedures for agricultural research 2nd ed. John Wiley \& Sons. NY.

Hayes, D.J. ; J.A. Fox and J.F. Shogren (2002). Experts and advocates: How information affects the demand for food irradiation. Food Policy, 27:185-193.

IAEA (1992). Irradiation of spices, herbs and other vegetable seasonings. IAEA-TECDOC-639.

IAEA (2007). Food Irradiation: A Powerful Nuclear Tool for Food Safety. Retrieved from: http://www.IAEA-food-irrad-tool0807S.

Johnson, H.W. ; H. F. Robinson and R.E. Comstock (1955). Estimates of genetic and environmental variability in soybeans. Agron. J., 47:314-308.

Kumar, A. ; M. L. Kushwaha ; A. Panchbhaiya and P. Verma (2017). Studies on genetic variability in different genotypes of Taro. J. of Hill Agric., 8 (3):274-278.

Kumari, K. and S. Kumar (2015). Effect of Gamma Irradiation on Vegetative and Propagule Characters in Gladiolus and Induction of Homeotic Mutants. Int. J. Agric. Env. and Biotech., 8 (2):413-422.

Moustafa, S.M. ; E.A. Agina ; Y.A.A. Ghatas and Y.A.M. El-Gazzar (2018). Effect of Gamma rays, Microwave and Colchicine on some Morphological and Cytological Characteristics of Gladiolus grandiflorus c v. White Prosperity. Middle East J. Agric. Res., 7 (4):1827-1839.

Mulualem, T. ; G. Welde Michael and K. Belachew (2013). Genetic Diversity of Taro (Colocasia esculenta (L.) Schott) Genotypes in Ethiopia Based on Agronomic Traits. Time J. of Arts and Educational Res., 1(2) 6-10.

Nurilmala, F. ; R. P. Hutagaol ; I. M. Widhyastini ; U. Widyastuti and Suharsono (2017). Somaclonal variation induction of Bogor taro (Colocasia esculenta) by gamma irradiation. Biodiversitas, 18 (1): 28-33. 
Oladosu, Y. ; M.Y. Rafii; N. Abdullah ; H. Ghazali ; R. Asfaliza ; H.A. Rahim ; G. Miah and M. Usman (2016). Principle and application of plant mutagenesis in crop improvement: A review. Biotechnology \& Biotechnological Equipment,30 (1):1-16.

Parry, M.A.J. ; P.J. Madgwick ; C. Bayon ; K. Tearall ; A. Hernandez-Lopez ; M. Baudo ; M. Rakszegi ; W. Hamada ; A. Al-Yassin ; H. Ouabbou ; M. Labhilili and A. L. Phillips (2009). Mutation discovery for crop improvement. Journal of Experimental Botany, 60 (10): 2817-2825.

Paul, K. K. ; M. A. Bari and S. C. Debnath (2011). Genetic variability of Colocasia esculenta (L.) Schott. Bangladesh J. Bot., 40(2): 185-188.

Penna, S. ; S. B. Vitthal and P. V. Yadav (2012). In vitro mutagenesis and selection in plant tissue cultures and their prospects for crop improvement. Global Science Book., 6 (1):6-14.

Puchooa, D. (2005). In vitro Mutation Breeding of Anthurium by Gamma Radiation. Int J Agri Bio., 7 (1): 11-20.

Robinson, H. F. ; R. E. Comstock and P. H. Harvey (1949). Estimates of heritability anddegree of dominance in corn. Agron. J., 41:353-359.

Rudyatmi, E. and S. R. Enni (2014). Central Java local taro characterization (identification of germplasm sources as an alternative food conservation effort). Department of Biology, Faculty of Mathematics and Natural Sciences, Semarang State University, 12 (1): .

Sahoo, M. R. ; B. B. Sahoo ; P.C. Kole ; A. Mukherjee ; S. S. Roy ; N. Prakashand and S. V. Ngachan (2012). Induction of stress tolerance and characterization of taro (Colocasia esculenta L. (Schott)) genotypes against Phytophthora leaf blight disease. In: Global Conference on Horticulture for Food, Nutrition and Livelihood Options, May 28-31, Bhubaneswar, p. 79.

Sivasubramanian, S. and M. Menon (1973). Heterosis and inbreeding depression in rice. Madras Agric. J., 60:1139-1140.

Tewodros, M. (2012). Diversity analysis of taro (Colocasia esculenta L.) Schott) in Ethiopia., Lambert Acadamic Publishing. Saarbrucken, Germany.

WHO (World Health Organization) (1988). Food Irradiation: A Technique for Preserving and Improving the Safety of Food (WHO Publication in Collaboration with FAO). pp. 144-149. 


\section{إحداث تغيرات وراثية في القلقاس بإستخدام اشعة جاما}

أماني حافظ عبدالله محمود غريب

مركز البحوث الزراعيه - معهد بحوث البساتين - قسم بحوث تربية الخضر والنباتات الطبية والعطرية

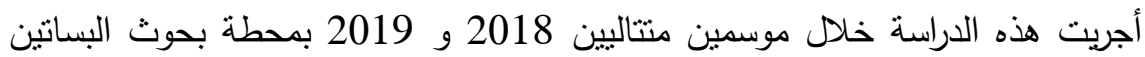

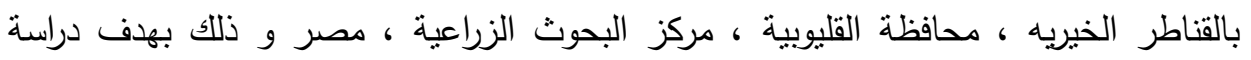

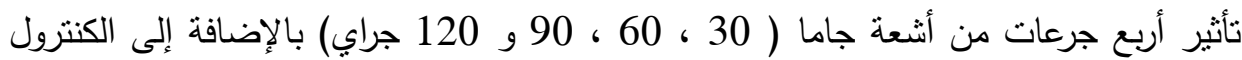

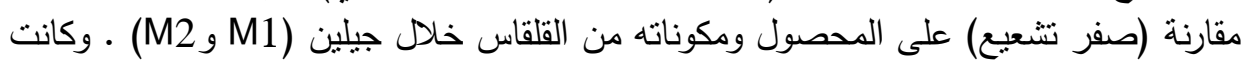
الجرعه 120 جراي ذو نأثنير مميت للنباتات.

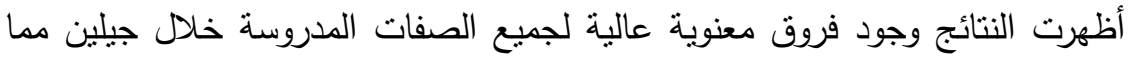

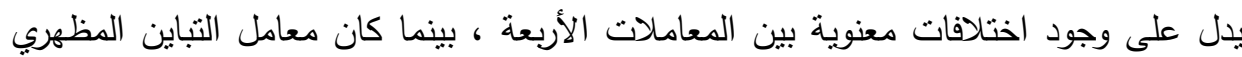

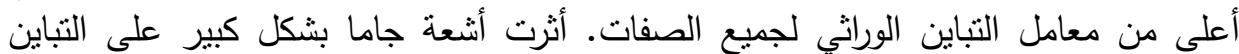

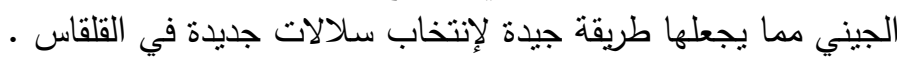

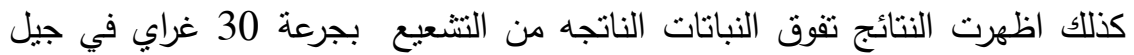

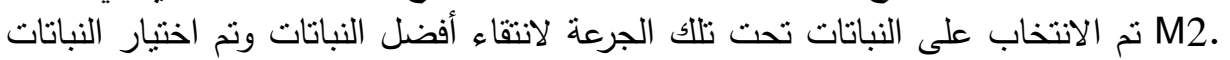

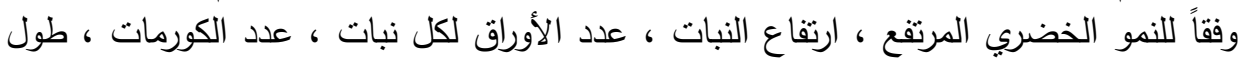

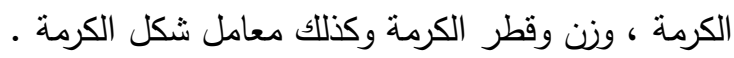

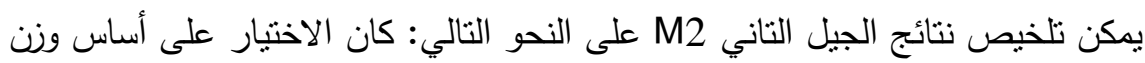

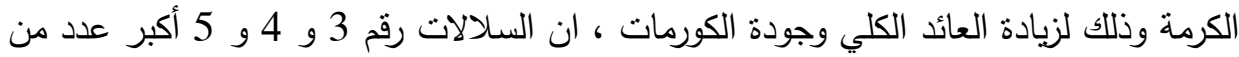
الكورمات / النبات وأعلى وزن للكورمة. 